\title{
FAKTOR - FAKTOR YANG MEMPENGARUHI KUALITAS AUDIT PADA INSPEKTORAT PROVINSI SULAWESI UTARA
}

\author{
Grace M. Turangan, Herman Karamoy, Jantje J. Tinangon \\ (email: garce.marvela.gmt@gmail.com)
}

\begin{abstract}
The purpose of this research is to examine the effect of the competence, experience, independence, objectivity, integrity and motivation auditor in North Sulawesi Provincial Inspectorate to audit quality. The study population was all auditors in Inspectorate of North Sulawesi province with a total sample of 60 auditors working in the Inspectorate of North Sulawesi province. The sampling technique used purposive approach / judgment sampling. The results of multiple regression analysis explains that the quality of the audit which is owned by the Inspectorate of North Sulawesi associated positively or direction of the competence, experience, independence, objectivity, integrity and motivation. the results of the study to simultaneously show that variables, Competence, experience, independence, objectivity, integrity and motivation together significantly influence the variable quality of the audit. While in partial competence, experience and independence not significant effect on audit quality otherwise variable objectivity, integrity and motivation have a significant effect on audit quality. The correlation coefficient $(R)$ of 0.803 indicates that the relationship between competence, experience, independence, objectivity, integrity and motivation have a relationship (correlation) is very strong on audit quality, as it approaches a value of 1 . The value of adjusted $R 2$ as the coefficient of determination is 0.605 , which means improvement of audit quality by $60.5 \%$ influenced by competence, experience, independence, objectivity, integrity and motivation, while the remaining $39.5 \%$ is influenced by other factors outside the research or explained by other variables not included in this study.

Key Words : Audit quality, competence, experience, independence, objectivity, integrity and motivation.
\end{abstract}

\section{PENDAHULUAN}

Pengawasan intern pemerintah merupakan fungsi manajemen yang penting dalam penyelenggaraan pemerintahan. Melalui pengawasan intern dapat diketahui apakah suatu instansi pemerintah telah melaksanakan kegiatan sesuai dengan tugas dan fungsinya secara efektif dan efisien, serta sesuai dengan rencana, kebijakan yang telah ditetapkan, dan ketentuan. Selain itu, pengawasan intern atas penyelenggaraan pemerintahan diperlukan untuk mendorong terwujudnya good governance dan clean government dan mendukung penyelenggaraan pemerintahan yang efektif, efisien, transparan, akuntabel serta bersih dan bebas dari praktik korupsi, kolusi, dan nepotisme (Permenpan, $2008: 5$ ).

Asosiasi Auditor Intern Pemerintah Indonesia (2013) dalam Standar Audit Intern Pemerintah Indonesia, menyatakan bahwa APIP (Aparat Pengawas Intern Pemerintah) sebagai pengawas intern pemerintah merupakan salah satu unsur manajemen pemerintah yang penting dalam rangka mewujudkan kepemerintahan yang baik (good governance) yang mengarah pada pemerintahan/birokrasi yang bersih (clean government). Untuk mencapai tujuan tersebut diperlukan peran APIP yang efektif. Peran APIP yang efektif dapat terwujud jika didukung dengan auditor yang profesional dan kompeten dengan hasil audit intern yang semakin berkualitas. Jadi auditor yang berkualitas akan menghasilkan audit yang berkualitas pula. Untuk mencapai hasil audit intern yang berkualitas maka pelaksanaan audit harus sesuai dengan Standar Audit yang ada. 
Kelancaran pelaksanaan tugas APIP perlu didukung dengan peraturan perundang undangan dan pedoman tentang pengawasan intern pemerintah yang merumuskan ketentuan ketentuan pokok dalam bidang pengawasan intern pemerintah dalam rangka menjamin terlaksananya pengawasan intern pemerintah yang efisien dan efektif. Kementerian Negara Pendayagunaan Aparatur Negara pada tahun 2008 telah melakukan penyusunan kode etik dan standar audit dan telah menerbitkannya dalam bentuk Peraturan Menteri Negara Pendayagunaan Aparatur Negara nomor Per/04/M.PAN/03/2008 tentang kode etik dan Per/05/M.PAN/03/2008 tentang standar audit. Penyusunan kode etik dan standar audit tesebut dimaksudkan agar pelaksanaan audit berkualitas, siapapun yang melaksanakannya diharapkan menghasilkan suatu mutu audit yang sama ketika auditor melaksanakan auditnya sesuai dengan kode etik dan standar audit yang bersangkutan.

Peraturan Menteri Negara Pendayagunaan Aparatur nomor 5 tahun 2008 tentang Standar Audit Aparat Pengawasan Intern Pemerintah (APIP) menyatakan bahwa, auditor adalah Pegawai Negeri Sipil (PNS) yang mempunyai jabatan fungsional auditor dan/atau pihak lain yang diberi tugas, wewenang, tanggung jawab dan hak secara penuh oleh pejabat yang berwenang melaksanakan pengawasan pada instansi pemerintah untuk dan atas nama APIP. Selanjutnya menurut Asosiasi Auditor Intern Pemerintah Indonesia (2013) dalam Standar Audit Intern Pemerintah Indonesia, pengertian auditor di atas mencakup Jabatan Fungsional Auditor (JFA) dan Jabatan Fungsional Pengawas Penyelenggaraan Urusan Pemerintahan di Daerah (JFP2UPD) yang berkedudukan sebagai pelaksana teknis fungsional bidang pengawasan di lingkungan APIP. Pemeriksaan yang dilakukan APIP terkadang menemui kendala dalam pelaksanaannya dimana adanya rasa kekeluargaan, kebersamaan dan pertimbangan manusiawi yang menonjol. Masalah lain yang dihadapi dalam peningkatan kualitas APIP adalah bagaimana meningkatkan sikap atau perilaku, kemampuan aparat pengawasan dalam melaksanakan pemeriksaan, sehingga pengawasan yang dilaksanakan dapat berjalan secara wajar, efektif dan efisien (Sukriah, dkk 2009). Prinsip - prinsip perilaku yang berlaku bagi auditor antara lain integritas, obyektifitas dan kompetensi. Integritas diperlukan agar auditor dapat bertindak jujur dan tegas dalam melaksanakan audit. Obyektifitas diperlukan agar auditor dapat bertindak adil tanpa dipengaruhi oleh tekanan atau permintaan pihak tertentu yang berkepentingan atas hasil audit serta kompetensi auditor didukung oleh pengetahuan, dan kemampuan yang diperlukan untuk melaksanakan tugas (Sukriah, dkk 2009). Apabila aparat pemeriksa yang berada didalamnya mempunyai motivasi yang tinggi terhadap pengawasan pengelolaan keuangan daerah, maka pemeriksa yang berada pada inspektorat maupun inspektorat itu sendiri akan mendapatkan pengakuan yang baik dan kepercayaan yang tinggi terhadap badan/organisasi tersebut dari stakeholder (Wirasuasti, 2014).

Selanjutnya untuk mendorong percepatan peningkatan kualitas tata kelola pemerintahan yang bersih, efektif dan terpercaya tersebut, Pemerintah di dalam Rencana Pembangunan Jangka Menengah Nasional (RPJMN) tahun 2015-2019 secara khusus telah memasukkan peningkatan kapabilitas APIP sebagai bagian dari agenda pembangunan. Hal ini dipertegas kembali oleh Presiden RI Bapak Joko Widodo pada Rapat Koordinasi Nasional Pengawasan Intern dengan tema Peningkatan Kapabilitas APIP tanggal 13 Mei 2015 di Jakarta. Salah satu perintah Presiden adalah agar kapabilitas APIP di setiap K/L/D pada akhir tahun 2019 berada pada Level 3 (Integrated), jika dinilai dengan menggunakan Internal Audit Capability Model (IACM) yang dikembangkan oleh The Institute of Internal Auditor (IIA) tahun 2009. Sebagaimana diketahui dalam kerangka IACM kapabilitas pengawasan intern dikelompokkan menjadi lima tingkatan, yaitu Level 1 (Initial), Level 2 (Infrastructure), Level 3 (Integrated), Level 4 (Managed), dan Level 5 (Optimazing). (BPKP, 2015).

Kapabilitas APIP se-Sulawesi termasuk Provinsi Sulawesi Utara saat ini masih berada di level 1 (initial) dimana Secara konseptual tingkatan kapabilitas level 1 tersebut dapat 
dipahami dengan makna bahwa di dalam pelaksanaan kegiatan pengawasannya belum atau tidak ada praktik pengawasan yang tetap, tidak ada kapabilitas yang berulang dan masih tergantung kepada kinerja auditor yang dimiliki sehingga APIP belum dapat memberikan jaminan atas proses tata kelola sesuai peraturan dan mencegah korupsi (BPKP, 2013).

Berdasarkan Hasil Pemeriksaan Kinerja atas Efektifitas Kegiatan Audit dan Reviu LK APIP Provinsi Sulawesi Utara tahun angaran 2012 dan semester I tahun 2013 oleh BPK RI Perwakilan Provinsi Sulawesi Utara bertujuan menilai efektifitas kegiatan audit dan reviu laporan keuangan yang dilakukan oleh APIP untuk meningkatkan akuntabilitas pengelolaan keuangan negara, maka dipaparkan pokok - pokok hasil pemeriksaan yang perlu mendapat perhatian antara lain disebutkan bahwa kompetensi tenaga pengawas pada Inspektorat Provinsi Sulawesi Utara belum memadai untuk mendukung kegiatan audit dan reviu Laporan Keuangan. Dimana pada pasal 18 ayat 2 Peraturan Menteri Dalam Negari tahun 2008, diatur bahwa Inspektorat Provinsi/Kabupaten/Kota melakukan reviu atas laporan keuangan dan kinerja dalam rangka meyakinkan keandalan informasi yang disajikan sebelum disampaikan oleh Gubernur/Bupati/Walikota kepada Badan Pemeriksa Keuangan (BPK). Pelaksanaan reviu dilakukan dengan tujuan untuk memberikan keyakinan terbatas bahwa laporan keuangan disajikan telah sesuai dengan SAP.

Berangkat dari kondisi tersebut, maka saya tertarik untuk meneliti faktor apa saja yang dapat mempengaruhi kualitas Audit Auditor Inspektorat Provinsi Sulawesi Utara, sehubungan dengan itu saya mengangkat judul : "Faktor - Faktor Yang Mempengaruhi Kualitas Audit Auditor Inspektorat Provinsi Sulawesi Utara".

\section{TINJAUAN PUSTAKA}

\section{Teori Atribusi}

Teori atribusi yang dikemukakan oleh Robbins (1996) menyatakan bahwa :

"Attribution theory has been proposed to develop explanations of the ways in which we judge people differently, depending on what meaning we attribute to a given behavior.2 Basically, the theory suggests that when we observe an individual's behavior, we attempt to determine whether it was internally or externally caused. That determination, however, depends largely on three factors: (1) distinctiveness, (2) consensus, and (3) consistency. First, let's clarify the differences between internal and external causation and then we will elaborate on each of the three determining factors. Internally caused behaviors are those believed to be under the personal control of the individual. Externally caused behavior is seen as resulting from outside causes; From an attribution perspective, if consensus is high, you would be expected to give an external attribution to the employee's tardiness, whereas if other employees who took the same route made it into work on time, your conclusion as to causation would be internal."

Teori atribusi menjelaskan perilaku seseorang yang disebabkan oleh faktor internal atau faktor eksternal. Dimana Robbins mengembangkan penjelasan tentang cara yang berbeda dalam menilai orang, tergantung pada atribut perilaku tertentu, yang ditunjukan oleh penyebab internal atau eksternal. Penyebab perilaku internal diyakini berada dibawah kendali pribadi individu. Penyebab perilaku eksternal dipandang sebagai akibat dari pengaruh luar yaitu perilaku yang terbentuk karena situasi.

Dalam penelitian ini, peneliti menggunakan teori atribusi karena akan melakukan penelitian untuk mengetahui faktor-faktor yang mempengaruhi auditor terhadap kualitas hasil audit, khususnya pada karakteristik personal auditor itu sendiri. Pada dasarnya karakteristik personal seorang auditor merupakan salah satu penentu terhadap kualitas hasil audit yang 
akan dilakukan karena merupakan suatu faktor internal yang mendorong seseorang untuk melakukan suatu aktivitas.

\section{Teori Behaviorisme}

Teori belajar behaviorisme adalah sebuah teori yang dicetuskan oleh Gage dan Berliner tentang perubahan tingkah laku sebagai hasil dari pengalaman (dalam Muh. Hizbul Muflihin, 2009:123). Teori psikologi behaviorisme adalah suatu teori belajar yang memandang kehidupan manusia terdiri atas unsur-unsur yang saling berhubungan satu dengan lainnya. Teori ini sangat menekankan pada perilaku yang dapat diamati dan diukur.

Teori behaviorisme ini memiliki tiga rumpun yang terdiri atas 1) teori connectionism dengan tokohnya Edward L. Thorndike; 2) conditioning classic dengan tokohnya Ivan Pavlov; dan 3) psikologi penguatan (operant conditioning) dengan tokoh yang terkenal yaitu B.F Skinner.

Teori behaviorisme dalam penelitian ini berhubungan dengan variabel kompetensi. Kompetensi yang dimiliki oleh auditor diperoleh dari hasil belajar secara terus menerus dan bukan merupakan sifat bawaan seseorang sehingga kompetensi dapat diukur. Reinforcement pada kompetensi dilakukan dengan adanya pengembangan kompetensi secara berkelanjutan melalui pelatihan, pendidikan maupun penugasan yang bertujuan untuk mempertahankan bahkan meningkatkan kompetensi yang dimiliki oleh seorang auditor.

Audit

Terdapat banyak definisi mengenai auditing, berikut ini akan disajikan beberapa definisi audit yaitu :

Menurut Mulyadi (2002) "Suatu proses sistematik untuk memperoleh dan mengevaluasi bukti secara obyektif mengenai pernyataan-pernyataan tentang kegiatan dan kejadian ekonomi, dengan tujuan untuk menetapkan tingkat kesesuaian antara pernyataan-pernyataan tersebut dengan kriteria yang telah ditetapkan, serta penyampaian hasil - hasilnya kepada pemakai yang berkepentingan".

Menurut Undang-Undang Republik Indonesia Nomor 15 tahun 2004 Tentang Pemeriksaan Pengelolaan dan Tanggung Jawab Keuangan Negara, "Pemeriksaan adalah proses identifikasi masalah, analisis, dan evaluasi yang dilakukan secara independen, obyektif, dan profesional berdasarkan standar pemeriksaan, untuk menilai kebenaran, kecermatan, kredibilitas, dan keandalan informasi mengenai pengelolaan dan tanggung jawab keuangan Negara"

Menurut Arens. A.A., R.J. Elder., dan M.S, Beasley (2015, 1-15) "auditing adalah pengumpulan dan evaluasi bukti tentang informasi untuk menentukan dan melaporkan derajat kesesuaian antara informasi itu dan kriteria yang telah ditetapkan. Auditing harus dilakukan oleh orang yang kompeten dan independen"

Audit pada umumnya dibagi menjadi tiga jenis utama, yaitu : audit laporan keuangan, audit kepatuhan, dan audit operasional.

\section{Audit Intern}

Definisi audit intern menurut Sawyer dalam Modul pusdiklatwas BPKP (2014) audit intern adalah sebuah penilaian sistematis dan objektif yang dilakukan auditor intern terhadap operasi dan control yang berbeda - beda dalam organisasi unutk menentukan apakah : (1) informasi keuangan dan operasi telah akurat dan dapat diandalkan; (2) risiko yang dihadapi perusahaan (organisasi) telah diidentifikasi dan minimalisasi; (3) peraturan ekstren serta kebijakan dan prosedur intern yang bisa diterima telah dipenuhi; (4) kriteria operasi (kegiatan) yang memuaskan telah dipenuhi; (5) sumberdaya telah digunakan secara efisien dan ekonomis; dan (6) tujuan organisasi telah dicapai secara efektif semua dilakukan dengan tujuan untuk dikonsultasikan dengan manajemen dan membantu anggota organisasi dalam menjalankan tanggungjawabnya secara efektif

\section{Aparat Pengawasan Intern Pemerintah (APIP)}


Sebagaimana diatur dalam Permenpan nomor PER/05/M.PAN/03/2008 tentang Standar Audit APIP. Aparat Pengawasan Intern Pemerintah (APIP) adalah Instansi Pemerintah yang mempunyai tugas pokok dan fungsi melakukan pengawasan. Adapun tugas pokok dan fungsi pengawasan yang dilakukan oleh Inspektorat adalah kegiatan yang meliputi (1) Pengawasan intern adalah seluruh proses kegiatan audit, reviu, pemantauan, evaluasi, dan kegiatan pengawasan lainnya berupa asistensi, sosialisasi dan konsultansi terhadap penyelenggaraan tugas dan fungsi organisasi dalam rangka memberikan keyakinan yang memadai bahwa kegiatan telah dilaksanakan sesuai dengan tolok ukur yang telah ditetapkan secara efektif dan efisien untuk kepentingan pimpinan dalam mewujudkan kepemerintahan yang baik. (2) Audit adalah proses identifikasi masalah, analisis, dan evaluasi bukti yang dilakukan secara independen, obyektif dan profesional berdasarkan standar audit, untuk menilai kebenaran, kecermatan, kredibilitas, efektifitas, efisiensi, dan keandalan informasi pelaksanaan tugas dan fungsi instansi pemerintah. (3) Reviu adalah penelaahan ulang bukti-bukti suatu kegiatan untuk memastikan bahwa kegiatan tersebut telah dilaksanakan sesuai dengan ketentuan, standar, rencana, atau norma yang telah ditetapkan. (4) Pemantauan adalah proses penilaian kemajuan suatu program/kegiatan dalam mencapai tujuan yang telah ditetapkan. (5) Evaluasi adalah rangkaian kegiatan membandingkan hasil/prestasi suatu kegiatan dengan standar, rencana, atau norma yang telah ditetapkan, dan menentukan faktor-faktor yang mempengaruhi keberhasilan atau kegagalan suatu kegiatan dalam mencapai tujuan. (6) Audit kinerja adalah audit atas pelaksanaan tugas dan fungsi instansi pemerintah yang terdiri atas audit aspek ekonomi, efisiensi, dan audit aspek efektifitas. (7) Audit investigatif adalah proses mencari, menemukan, dan mengumpulkan bukti secara sistematis yang bertujuan mengungkapkan terjadi atau tidaknya suatu perbuatan dan pelakunya guna dilakukan tindakan hukum selanjutnya.

\section{Kualitas Audit}

Sampai saat ini belum ada definisi yang pasti mengenai apa dan bagaimana kualitas audit yang baik. Tidak mudah untuk menggambarkan dan mengukur kualitas audit secara obyektif dengan beberapa indikator. Hal ini dikarenakan kualitas audit merupakan sebuah konsep yang kompleks dan sulit dipahami, sehingga sering kali terdapat kesalahan dalam menentukan sifat dan kualitasnya. Hal ini terbukti dari banyaknya penelitian yang menggunakan dimensi kualitas audit yang berbeda-beda.

DeAngelo (1981b:186) menyatakan bahwa:

The quality of audit services is defined to be the market-assessed joint probability that a given auditor will both (a) discover a breach in the client's accounting system, and (b) report the breach. The probability that a given auditor will discover a breach depends on the auditor's technological capabilities, the audit procedures employed on a given audit, the extent of sampling, etc. The conditional probability of reporting a discovered breach is a measure of an auditor's independence from a given client.

Jadi kualitas audit didefinisikan sebagai gabungan antara penilaian pasar dengan probabilitas bahwa auditor akan: (a) menemukan pelanggaran pada sistem akuntansi klien, dan (b) melaporkan pelanggaran tersebut. Kemungkinan bahwa auditor akan menemukan pelanggaran tergantung pada kompetensi auditor berupa kemampuan teknologi auditor, prosedur audit yang digunakan pada audit yang diberikan, dan sampling yang digunakan. Kemungkinan auditor akan melaporkan pelanggaran yang ditemukan adalah ukuran independensi auditor tersebut.

Jadi kualitas audit bergantung pada individu-individu kompeten yang menggunakan pengalaman mereka dan menerapkan integritas, objektivitas, dan skeptisisme yang memungkinkan mereka untuk membuat penilaian yang tepat yang didukung oleh fakta fakta dan keadaan pada saat pelaksanaan audit. Kualitas ketekunan dan ketahanan dari 
seorang auditor juga penting dalam memastikan bahwa perubahan yang diperlukan terhadap laporan keuangan, atau, kondisi dimana tidak perlu dilakukan perubahan, untuk memastikan bahwa laporan auditor tersebut benar-benar wajar.

\section{Kompetensi}

Government Internal Audit Profession (2007) dalam Government Internal Audit Competency Framework menyatakan bahwa :

"A common definition is that competencies are: Clusters of behaviours, skills and knowledge which are needed to undertake a job effectively."

Jadi kompetensi didefinisikan secara umum sebagai gabungan dari perilaku, keterampilan dan pengetahuan yang dibutuhkan untuk melakukan pekerjaan secara efektif.

Government Accountability Office (2011) Dalam Government auditing Standards chapter 3 tentang General Standards menyatakan bahwa :

"Maintaining competence through a commitment to learning and development throughout an auditor's professional life is an important element for auditors."

Jadi Mempertahankan kompetensi melalui komitmen untuk belajar dan pengembangan seluruh kehidupan profesional seorang auditor merupakan elemen penting bagi auditor.

\section{Pengalaman Kerja}

Yuniarsih dan Suwatno (2013) menyatakan bahwa, pengalaman kerja yaitu pengalaman seseorang tenaga kerja untuk melakukan pekerjaan tertentu. Pengalaman kerja dinyatakan dalam : (a) pekerjaaan yang harus dilakukan (b) lamanya melakukan pekerjaan itu. Faktor pengalaman perlu mendapat pertimbangan karena ada kecenderungan, makin lama bekerja, makin banyak pengalaman yang dimiliki dan sebaliknya makin singkat masa kerja, makin sedikit pengalaman yang diperoleh.

Ardana, dkk (2012) menyatakan bahwa, pengalaman bekerja yang banyak memberikan kecenderungan bahwa yang bersangkutan memiliki keahlian dan ketrampilan yang relatif tinggi. Pengalaman kerja yang dimiliki seseorang lebih banyak membantunya dalam mengerjakan sesuatu dibandingkan dengan pendidikan yang diikutinya.

\section{Independensi}

Mulyadi (2002:26) mendefinisikan independensi sebagai sikap mental yang bebas dari pengaruh, tidak dikendalikan oleh pihak lain, tidak tergantung pada orang lain. Independensi juga berarti adanya kejujuran dalam diri auditor dalam mempertimbangkan fakta dan adanya pertimbangan yang obyektif tidak memihak dalam diri auditor dalam merumuskan dan menyatakan pendapatnya. Jadi independensi didefinisikan sebagai "keadaan bebas dari pengaruh, tidak dikendalikan oleh pihak lain, tidak tergantung pada pihak lain" dan auditor yang independen haruslah auditor yang tidak terpengaruh dan tidak dipengaruhi oleh berbagai kekuatan yang berasal dari luar diri akuntan dalam mempertimbangkan fakta yang dijumpainya dalam pemeriksaan.

Arens dkk ( 2015) mendefinisikan independensi dalam pengauditan sebagai "penggunaan cara pandang yang tidak bias dalam pelaksanaan pengujian audit, evaluasi hasil pengujian tersebut dan pelaporan hasil temuan audit".

The Institute of Internal Auditors (2012) dalam International Standards for the

Professional Practice of Internal Auditing (Standards) menyatakan bahwa :

Independence is the freedom from conditions that threaten the ability of the internal audit activity to carry out internal audit responsibilities in an unbiased manner.

\section{Obyektifitas}

Obyektifitas adalah suatu kualitas yang memberikan nilai atas jasa yang diberikan anggota. Prinsip obyektifitas mengharuskan anggota bersikap adil, tidak memihak, jujur secara intelektual, tidak berprasangka atau bias serta bebas dari benturan kepentingan atau 
berada dibawah pengaruh pihak lain (Mulyadi, 2002-57). Menurut Arens, dkk (2015) bebas dari konflik kepentingan berarti tidak ada hubungan yang dapat mencampuri objektifitas atau integritas.

The Institute of Internal Auditors (2012) dalam International Standards for the Professional Practice of Internal Auditing (Standards) menyatakan bahwa :

Objectivity is an unbiased mental attitude that allows internal auditors to perform engagements in such a manner that they believe in their work product and that no quality compromises are made. Objectivity requires that internal auditors do not subordinate their judgment on audit matters to others.

Jadi Objektivitas adalah sikap mental yang benar/tidak bias sehingga memungkinkan auditor internal untuk melakukan keterlibatan sedemikian rupa bahwa mereka percaya pada hasil pekerjaan mereka dan bahwa tidak ada kompromi kualitas yang dibuat. Objektivitas mengharuskan penilaian tentang hal-hal audit yang dibuat oleh auditor internal tidak dibawah pengaruh orang lain.

Integritas

Integritas adalah suatu elemen karakter yang mendasari timbulnya pengakuan professional. Integritas merupakan kualitas yang mendasari kepercayaan publik dan merupakan patokan bagi anggota dalam menguji semua keputusan yang diambilnya. Integritas diukur dalam bentuk apa yang benar dan adil (Mulyadi, 2002-56). Menurut Arens, dkk (2015) bebas dari konflik kepentingan berarti tidak ada hubungan yang dapat mencampuri objektifitas atau integritas.

Sebagaimana yang diatur dalam Permenpan No. PER/05/M.PAN/03/2008 tentang kode etik APIP menyebutkan bahwa prinsip - prinsip yang wajib dipatuhi oleh auditor salah satunya adalah integritas dimana Auditor harus memiliki kepribadian yang dilandasi oleh unsur jujur, berani, bijaksana, dan bertanggung jawab untuk membangun kepercayaan guna memberikan dasar bagi pengambilan keputusan yang andal.

\section{Motivasi}

Menurut Ardana, dkk (2012) motivasi adalah kekuatan yang mendorong seseorang untuk melakukan suatu tindakan atau tidak. Sedangkan motivasi kerja adalah sesuatu yang menimbulkan dorongan atau semangat kerja atau pendorong semangat kerja. Suwandi (2005), dalam blog mahasiswa akuntansi Indonesia dalam konteks organisasi, motivasi adalah pemaduan antara kebutuhan organisasi dengan kebutuhan personil. Hal ini akan mencegah terjadinya ketegangan / konflik sehingga akan membawa pada pencapaian tujuan organisasi secara efektif. Wirasuasti (2014), menyatakan bahwa apabila dikaitkan dengan teori kebutuhan, maka motivasi sangat berkaitan dengan proses audit yang dilakukan. Dalam teori kebutuhan terdapat lima jenjang kebutuhan manusia yang terdiri dari: kebutuhan fisiologis, kebutuhan rasa aman, kebutuhan sosial, kebutuhan akan penghargaan/prestise, dan kebutuhan aktualisasi diri. Pada kebutuhan yang keempat, kebutuhan akan penghargaan maka seseorang akan melakukan suatu tindakan agar mendapatkan pengakuan dari orang lain.

Dalam modul Pusdiklatwas BPKP (2007) tentang kepemimpinan, menyatakan bahwa kepemimpinan merupakan suatu upaya dari seorang pemimpin untuk dapat merealisasikan tujuan organisasi melalui orang lain dengan cara memberikan motivasi agar orang lain tersebut mau melaksanakannya. Dengan demikian agar dapat menggerakkan anggotanya, seorang ketua tim harus mampu memotivasi anggotanya. Motivasi seseorang dapat ditingkatkan jika perlakuan pihak lain dapat memberikan stimulus yang mampu menimbulkan respon secara positif. Untuk ini seorang ketua tim harus memiliki sarana yang dapat diperankan untuk dijadikan stimulus. Tim dapat dikembangkan jika para anggota di dalam tim (termasuk ketuanya) merasa puas bekerja dan ada motivasi untuk melaksanakan tugas-tugasnya. Selanjutnya dalam modul Pusdiklatwas BPKP (2008) tentang Supervisi audit, menyatakan bahwa dalam suatu tim yang melaksanakan audit perlu tercipta suasana 
yang memberikan motivasi kerja, hal ini merupakan salah satu tugas pokok dari supervisor atau pengendali teknis.

\section{KERANGKA KONSEPTUAL Kerangka Konseptual}

Kerangka konseptual merupakan konseptual tentang bagaimana teori berhubungan dengan berbagai faktor yang telah diidentifikasi sebagai masalah penting (Sekaran, 1992; Sugiyono, 2014). Berdasarkan latar belakang masalah, rumusan permasalahan, dan teori yang ada maka kerangka konseptual dari penelitian ini adalah sebagai berikut :

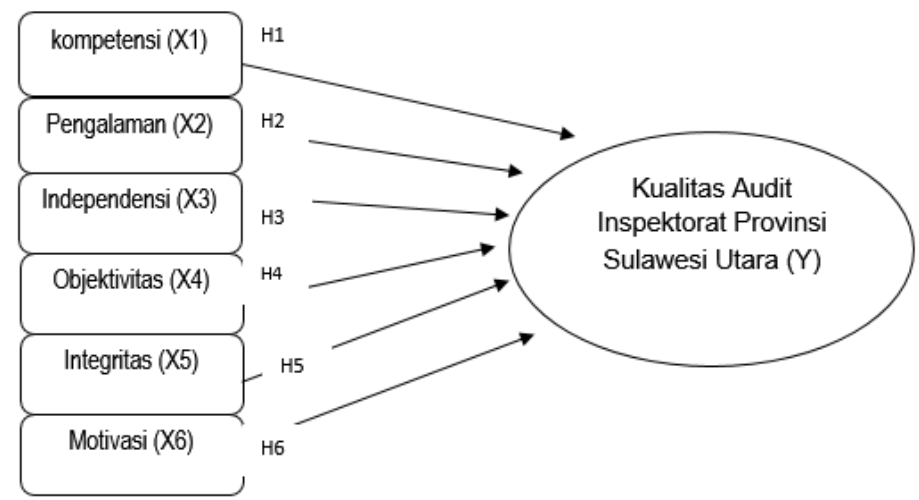

Permenpan nomor 19 tahun 2009 tentang Pedoman Kendali Mutu Audit yang menyatakan bahwa untuk mencapai mutu audit yang tinggi maka diperlukan kriteria standar yang harus dimiliki para auditor APIP, yaitu latar belakang pendidikan serta sikap dan perilaku.

\section{Hipotesis Penelitian}

\section{Pengaruh Kompetensi Terhadap Kualitas Audit}

Peraturan Kepala Badan Pengawasan Keuangan dan Pembangunan Nomor PER211/K/JF/2010 tentang Standar Kompetensi Auditor menyatakan bahwa, kompetensi adalah kemampuan dan karakteristik yang dimiliki oleh seorang Pegawai Negeri Sipil berupa pengetahuan, keahlian, dan sikap perilaku yang diperlukan dalam pelaksanaan tugas jabatannya. Government Internal Audit Profession (2007) menyatakan bahwa kompetensi adalah gabungan dari perilaku, keterampilan dan pengetahuan yang dibutuhkan untuk melakukan pekerjaan secara efektif. Standar Audit Intern Pemerintah Seksi 2120 paragraf 24 menyatakan bahwa Auditor wajib memiliki pengetahuan dan akses atas informasi teraktual dalam standar, metodologi, prosedur, dan teknik. Oleh karena itu, APIP selaku auditor internal Pemerintah dalam melaksanakan tugasnya harus senantiasa mengerahkan seluruh kompetensi yang dimiliki agar audit yang dilakukan sesuai dengan Standar Audit Intern Pemerintah.

Penelitian yang dilakukan Sukriah (2009) pada seluruh Pegawai Negeri Sipil (PNS) yang bekerja pada Inspektorat sepulau Lombok sebagai populasi penelitian, menunjukkan bahwa kompetensi berpengaruh positif dan signifikan terhadap kualitas audit. Penelitian Sukriah (2009) mendukung penelitian yang dilakukan oleh Efendy, (2010); Ayuningtyas dan Pamudji, (2012); dan Badjuri, (2012); Perdany dan Suranta, (2013) Musdar, (2014); dan Wirasuasti dkk., (2014) menyatakan bahwa kompetensi berpengaruh positif dan signifikan terhadap kualitas audit. Hasil tersebut dapat dipahami bahwa untuk meningkatkan kualitas audit, seorang auditor sangat bergantung pada tingkat kompetensinya. Jika auditor memiliki kompetensi yang baik maka auditor akan dengan mudah melakukan tugas tugas auditnya dan sebaliknya jika rendah maka dalam melaksanakan tugasnya, auditor akan mendapatkan kesulitan-kesulitan sehingga kualitas audit yang dihasilkan akan rendah pula. 
Berdasarkan teori dan penelitian sebelumnya maka hipotesis yang diajukan dalam penelitian ini adalah :

$H_{1}$ : Kompetensi berpengaruh positif dan signifikan terhadap kualitas audit Inspektorat. Pengaruh Pengalaman Terhadap Kualitas Audit

Auditor yang berpengalaman akan memiliki keunggulan dalam hal: 1) mendeteksi kesalahan, 2) memahami kesalahan secara akurat, dan 3) mencari penyebab kesalahan. Maka jika auditee mempersepsikan bahwa auditor berpengalaman, setelah mengamati sikap yang ditunjukkan auditor selama melakukan pemeriksaan, kecenderung auditee akan menilai tim audit tersebut berkualitas dan menimbulkan kepuasan auditee (Tubb, 1992; Zawitri, 2009).

Penelitian yang dilakukan Nataline (2007) pada auditor kantor Akuntan Publik di Semarang, menunjukkan bahwa ada pengaruh positif dan signifikan pengalaman kerja terhadap kualitas audit. Auditor yang tidak berpengalaman akan melakukan atribusi kesalahan lebih besar dibandingkan dengan auditor yang berpengalaman. Sama halnya dengan penelitian yang dilakukan oleh Sukriah, dkk (2009); Mabruri dan Winarna, (2010); Prasetyo (2016) yang berhasil membuktikan bahwa bahwa pengalaman kerja berpengaruh positif terhadap kualitas hasil pemeriksaan karena lama bekerja adalah sebagai suatu ukuran tentang lama waktu masa kerjanya yang telah ditempuh seseorang dalam memahami tugas tugas suatu pekerjaan dan telah dilaksanakannya dengan baik. Hal ini menunjukkan bahwa semakin banyak pengalaman kerja seorang auditor maka semakin meningkat kualitas auditnya. Berdasarkan teori dan penelitian sebelumnya maka hipotesis yang diajukan dalam penelitian ini adalah :

$\mathrm{H}_{2}$ : Pengalaman berpengaruh positif dan signifikan terhadap kualitas audit Inspektorat. Pengaruh Independensi Terhadap Kualitas Audit

Mulyadi (2002:26) mendefinisikan independensi sebagai sikap mental yang bebas dari pengaruh, tidak dikendalikan oleh pihak lain, tidak tergantung pada orang lain. Independensi juga berarti adanya kejujuran dalam diri auditor dalam mempertimbangkan fakta dan adanya pertimbangan yang obyektif tidak memihak dalam diri auditor dalam merumuskan dan menyatakan pendapatnya. Auditor yang independen adalah auditor yang tidak memihak atau tidak dapat diduga memihak, sehingga tidak merugikan pihak manapun (Pusdiklatwas BPKP, 2008).

Hasil penelitian Lubis (2009) pada Auditor Inspektorat Provinsi Sumatera Utara secara empiris membuktikan bahwa independensi berpengaruh secara signifikan terhadap kualitas audit. Penelitian tersebut sejalan dengan penelitian dan Wirasuasti (2014) yang menyatakan bahwa independensi berpengaruh secara signifikan terhadap kualitas audit. Suatu proses audit tidak dibenarkan memihak kepada siapapun, karena apabila seorang auditor kehilangan sikap independensinya walaupun memiliki kompetensi yang tinggi, maka auditor tersebut tidak akan bisa untuk mempertahankan kebebasan pendapatnya. Kerjasama dengan klien yang terlalu lama bisa menimbulkan kerawanan atas independensi yang dimiliki auditor. Selain itu juga berbagai fasilitas yang disediakan oleh kliennya selama penugasan audit untuk auditor. Sehingga auditor akan berada pada posisi yang dilematis karena mungkin akan mudah dikendalikan oleh auditan. Sehingga untuk menjaga tingkat independensi sangatlah tidak mudah agar tetap sesuai dengan jalur yang seharusnya. Independensi mempunyai peranan yang penting dalam meningkatkan kualitas audit ini berarti bahwa semakin auditor mampu menjaga independensinya dalam menjalankan penugasan profesionalnya maka kualitas audit yang dihasilkan akan semakin baik.

Berdasarkan teori dan penelitian sebelumnya maka hipotesis yang diajukan dalam penelitian ini adalah :

$H_{3}: \quad$ Independensi berpengaruh positif dan signifikan terhadap kualitas audit Inspektorat. 


\section{Pengaruh Obyektifitas Terhadap Kualitas Audit}

Pusdiklatwas BPKP (2008) menyatakan bahwa prinsip obyektifitas mengharuskan auditor bersikap adil, tidak memihak, tidak berprasangka atau bias, serta bebas dari benturan kepentingan atau berada di bawah pengaruh pihak lain, sehingga dapat mengemukaan pendapat menurut apa adanya.

Penelitian Ayuningtias dan Pamudji (2012) pada auditor yang bekerja di Inspektorat Kota Semarang, Kabupaten Semarang, Kabupaten Kendal, Kota Pekalongan dan Kabupaten Salatiga menunjukkan bahwa obyektifitas berpengaruh secara positif dan signifikan terhadap kualitas audit. Penelitian ini didukung oleh penelitian Sukriah, dkk.,(2009); Hal ini menunjukkan bahwa semakin tinggi tingkat obyektifitas auditor maka semakin baik kualitas hasil pemeriksaannya. Berdasarkan teori dan penelitian sebelumnya maka hipotesis yang diajukan dalam penelitian ini adalah :

\section{$H_{4}$ : Objektivitas berpengaruh positif dan signifikan terhadap kualitas audit Inspektorat.}

\section{Pengaruh Integritas Terhadap Kualitas Audit}

Integritas adalah suatu elemen karakter yang mendasari timbulnya pengakuan professional. Integritas merupakan kualitas yang mendasari kepercayaan publik dan merupakan patokan bagi anggota dalam menguji semua keputusan yang diambilnya. Integritas diukur dalam bentuk apa yang benar dan adil (Mulyadi, 2002).

Penelitian yang dilakukan oleh Mabruri dan Winarna, (2010) pada Pegawai Negeri Sipil (PNS) yang bekerja pada Inspektorat tingkat kota/kabupaten atau Bawasda di Surakarta, Karanganyar, Sukoharjo, dan Wonogiri berhasil membuktikan bahwa berpengaruh secara positif dan signifikan terhadap kualitas audit. Penelitian ini sejalan dengan penelitian yang dilakukan oleh Ayuningtyas dan Pamudji, (2012); Oklivia dan Marlinah, (2014); Musdar, (2014); Prasetyo, (2016); dan Badjuri, (2012) yang menyatakan bahwa Integritas merupakan perwujudan dari kejujuran auditor dalam melakukan penugasan secara profesional, dengan kejujuran dalam mengungkapkan temuan audit maka kualitas hasil pemeriksaan akan terjaga. Dengan integritas yang tinggi, maka auditor dapat meningkatkan kualitas hasil pemeriksaannya (Pusdiklatwas BPKP, 2008)

Berdasarkan teori dan penelitian sebelumnya maka hipotesis yang diajukan dalam penelitian ini adalah :

$H_{5}$ : $\quad$ Integritas berpengaruh positif dan signifikan terhadap kualitas audit Inspektorat.

\section{Pengaruh Motivasi Terhadap Kualitas Audit}

Penelitian yang dilakukan oleh Efendy (2010) pada aparat Inspektorat Kota Gorontalo, menyatakan bahwa motivasi berpengaruh secara positif dan signifikan terhadap kualitas audit. Demikian pula dengan penelitian Suli, (2009) dan Wirasuasti (2014) turut mendukung hasil penelitian ini. Goleman (2001) dalam Efendy (2010) menyatakan bahwa hanya motivasi yang akan membuat seseorang mempunyai semangat juang yang tinggi untuk meraih tujuan dan memenuhi standar yang ada. Respon atau tindak lanjut yang tidak tepat terhadap laporan audit dan rekomendasi yang dihasilkan akan dapat menurunkan motivasi aparat untuk menjaga kualitas audit.

Wirasuasti (2014), menyatakan bahwa seorang auditor yang melakukan audit dengan baik maka akan mendapatkan pengakuan yang baik juga dari lingkungannya. Begitupun juga dengan suatu badan/organisasi independen yang bertugas melakukan pemeriksaan maupun pengawasan terhadap pengelolaan keuntungan daerah yang dalam hal ini adalah inspektorat. Apabila aparat pemeriksa yang berada di dalamnya mempunyai motivasi yang tinggi terhadap pengawasan pengelolaan keuangan daerah, maka pemeriksa yang berada pada inspektorat maupun inspektorat itu sendiri akan mendapatkan pengakuan yang baik dan kepercayaan yang tinggi terhadap badan/organisasi tersebut dari stakeholder. Dalam modul Pusdiklatwas BPKP (2007) tentang kepemimpinan seorang ketua tim harus mampu memotivasi anggotanya, sehingga Tim dapat dikembangkan jika para anggota di dalam tim 
(termasuk ketuanya) merasa puas bekerja dan ada motivasi untuk melaksanakan tugastugasnya. Selanjutnya dalam modul Pusdiklatwas BPKP (2008) tentang Supervisi audit, menyatakan bahwa dalam suatu tim yang melaksanakan audit perlu tercipta suasana yang memberikan motivasi kerja, hal ini merupakan salah satu tugas pokok dari supervisor atau pengendali teknis. Sehingga adanya supervisi yang baik dari ketua tim terhadap anggota tim serta supervisi dari pengendali teknis kepada tim audit maka akan menambah semangat dari auditor/aparat untuk meningkatkan kualitas auditnya.

Berdasarkan teori dan penelitian sebelumnya maka hipotesis yang diajukan dalam penelitian ini adalah :

$H_{6}$ : $\quad$ Motivasi berpengaruh positif dan signifikan terhadap kualitas audit Inspektorat.

\section{METODE PENELITIAN Jenis Penelitian}

Jenis penelitian yang akan digunakan adalah metode kuantitatif. Menurut. Berdasarkan hubungan antara variabel yang diteliti, maka penelitian ini merupakan penelitian asosiatif kausal yaitu hubungan yang bersifat sebab-akibat. Jadi penelitian ini akan menguji pengaruh variabel independen yaitu kompetensi, pengalaman, independensi, obyektifitas, integritas dan motivasi terhadap variabel dependen yaitu kualitas audit.

\section{Populasi Sampel, Besaran Sampel Dan Teknik Pengambilan Sampel}

Populasi penelitian ini adalah auditor yang berada di Inspektorat Provinsi Sulawesi Utara sejumlah 52 orang auditor dan 28 orang calon auditor. Sampel penelitian ini adalah auditor yang berada di Inspektorat Provinsi Sulawesi Utara sejumlah 37 orang auditor yang terdiri dari Jabatan Fungsional Auditor/P2UPD dan 23 orang calon auditor. Teknik pengambilan sampel dilakukan dengan pendekatan purposive/judgement sampling yaitu auditor Inspektorat Provinsi Sulawesi Utara yang memiliki Jabatan Fungsional Auditor/P2UPD dan calon auditor yaitu calon Pejabat Fungsional Auditor/P2UPD yang telah mengikuti serta telah lulus sertifikasi Jabatan Fungsional Auditor/P2UPD. Judgement sampling adalah salah satu jenis purposive sampling di mana peneliti memilih sampel berdasarkan penilaian terhadap beberapa karakteristik anggota sampel yang disesuaikan dengan maksud penelitian (Kuncoro, 2013). Data yang digunakan dalam penelitian ini adalah data primer, yaitu data diperoleh melalui kuesioner yang langsung disebarkan kepada para responden. Setiap jawaban dari pernyataan dalam kuisioner tersebut telah ditentukan skornya berdasarkan skala Likert 5 poin yaitu (1) Sangat Tidak Setuju, (2) Tidak Setuju, (3) RaguRagu, (4) Setuju, dan (5) Sangat Setuju. Responden diminta untuk menyatakan setuju atau ketidaksetujuannya terhadap pernyataan yang diajukan sesuai dengan kondisi mereka yang sesungguhnya. Kuisioner merupakan teknik pengumpulan data yang dilakukan dengan cara memberi seperangkat pertanyaan atau pernyataan tertulis kepada responden untuk dijawabnya (Sugiyono, 2014).

\section{Lokasi Dan Waktu Penelitian}

Obyek dalam penelitian ini mengambil lokasi di Inspektorat Provinsi Sulawesi Utara dengan waktu penelitian selama 1 (satu) bulan yaitu selama bulan Agustus 2016.

\section{Klasifikasi Variabel Dan Defenisi Operasional Variabel} Klasifikasi Variabel

Penelitian ini akan menguji pengaruh variabel independen yang terdiri dari kompetensi, pengalaman, independensi, obyektifitas, integritas, dan motivasi terhadap variabel dependen yaitu kualitas hasil audit.

\section{Definisi Operasional Variabel}

Variabel Independen dalam penelitian ini adalah kompetensi, pengalaman, independensi, obyektifitas, integritas, dan motivasi. Sedangkan variabel dependen adalah kualitas audit APIP. 
Tabel 4.3.

Operasionalisasi Variabel dan Skala Pengukuran Variabel

\begin{tabular}{|c|c|c|c|}
\hline Variabel & Dimensi & Indikator & $\begin{array}{l}\text { No. Item } \\
\text { Pernyataan }\end{array}$ \\
\hline \multirow{7}{*}{$\begin{array}{c}\text { Kompetensi } \\
\left(\mathrm{X}_{1}\right) \\
\text { Perka BPKP No. PER- } \\
\text { 211/K/JF/2010 (2010); } \\
\text { Government Internal Audit } \\
\text { Profession (2007) }\end{array}$} & \multirow[t]{4}{*}{$\begin{array}{l}\text { Kompetensi } \\
\text { Inti }\end{array}$} & $\begin{array}{l}\text { Manajemen risiko, pengendalian internal } \\
\text { dan tata kelola sektor publik }\end{array}$ & $1-7$ \\
\hline & & Strategi Pengawasan & $8-12$ \\
\hline & & Pelaporan Hasil Pengawasan & $13-14$ \\
\hline & & Sikap Profesional & $15-18$ \\
\hline & \multirow{2}{*}{$\begin{array}{l}\text { Kompetensi } \\
\text { Pendukung }\end{array}$} & Komunikasi & $19-21$ \\
\hline & & Lingkungan Pemerintahan & 22 \\
\hline & $\begin{array}{l}\text { Kompetensi } \\
\text { Manajerial }\end{array}$ & Manajemen Pengawasan & $23-24$ \\
\hline \multirow{2}{*}{$\begin{array}{c}\text { Pengalaman }\left(\mathrm{X}_{2}\right) \\
\text { Ardana, dkk (2012); Yuniarsih } \\
\text { dan Suwatno (2013) }\end{array}$} & & Lamanya bekerja sebagai auditor & $1-6$ \\
\hline & & Banyaknya Tugas Pemeriksaan & $7-14$ \\
\hline \multirow{2}{*}{\multicolumn{2}{|c|}{$\begin{array}{c}\text { Independensi }\left(\mathrm{X}_{3}\right) \\
\text { Mulyadi (2002); Arens dkk }\end{array}$}} & Independensi penyusunan program & $1-3$ \\
\hline & & Independensi pelaksanaan pekerjaan & $4-6$ \\
\hline \multirow{3}{*}{$\begin{array}{l}\text { (2015); The Institute } \\
\text { Internal Auditors (2012) }\end{array}$} & & Independensi pelaporan & $7-9$ \\
\hline & & Gangguan intern & $10-13$ \\
\hline & & Gangguan ekstern & $14-15$ \\
\hline \multirow{2}{*}{$\begin{array}{l}\text { Obyektifitas }\left(\mathrm{X}_{4}\right) \text { Mulyadi } \\
\text { (2002); Arens dkk ( 2015); The } \\
\text { Institute of Internal Auditors } \\
\text { (2012) }\end{array}$} & & Bebas dari benturan kepentingan & $1-4$ \\
\hline & & Pengungkapan kondisi sesuai fakta & $5-8$ \\
\hline \multirow{4}{*}{$\begin{array}{c}\text { Integritas }\left(\mathrm{X}_{5}\right) \\
\text { Mulyadi (2002); Arens dkk ( } \\
\text { 2015); }\end{array}$} & & Kejujuran APIP & $1-3$ \\
\hline & & Keberanian APIP & $4-6$ \\
\hline & & Sikap Bijaksana APIP & $7-9$ \\
\hline & & Tanggungjawab APIP & $10-14$ \\
\hline \multirow{8}{*}{$\begin{array}{c}\text { Motivasi }\left(\mathrm{X}_{6}\right) \\
\text { Ardana, dkk (2012); Goleman } \\
\text { (2001); Larkin (1990) }\end{array}$} & & $\begin{array}{l}\text { Tingkat Aspirasi: Urgensi Audit yang } \\
\text { Berkualitas }\end{array}$ & $1-4$ \\
\hline & & Ketangguhan & 5 \\
\hline & & Keuletan & $6-7$ \\
\hline & & Konsistensi & $8-9$ \\
\hline & & Tunjangan & 10 \\
\hline & & Rewaard & 11 \\
\hline & & Lembur & 13 \\
\hline & & Suasana kerja & $14-18$ \\
\hline \multirow{8}{*}{$\begin{array}{c}\text { Kualitas Audit (Y) } \\
\text { DeAngelo (1981); PCAOB } \\
\text { (2013), IAASB(2013) }\end{array}$} & & $\begin{array}{l}\text { Kesesuaian pemeriksaan dengan standar } \\
\text { audit }\end{array}$ & $1-5$ \\
\hline & & Keakuratan temuan audit & $6-7$ \\
\hline & & Sikap skeptic & 8 \\
\hline & & Kejelasan laporan & 9 \\
\hline & & Kualitas hasil laporan pemeriksaan & $10-16$ \\
\hline & & Nilai rekomendasi & 17 \\
\hline & & Manfaat audit & 18 \\
\hline & & Tindak lanjut hasil audit & 19-20 \\
\hline
\end{tabular}

\section{Instrumen Penelitian}

\section{Uji Validitas dan Reliabilitas}

Uji validitas adalah untuk menguji dan mengetahui sah tidaknya instrumen kuisioner yang digunakan dalam pengumpulan data. Uji validitas ini dilakukan untuk mengetahui apakah item-item yang tersaji dalam kuesioner benar-benar mampu mengungkapkan dengan pasti apa yang akan diteliti (Ghozali, 2006). Uji reliabilitas dilakukan dengan cara menghitung nilai cronbach alpha dari masing-masing instrumen dalam suatu variabel. Reliabilitas menunjukan konsistensi stabilitas dari suatu skor (skala pengukuran). Reliabilitas 
berbeda dengan validitas karena yang pertama memusatkan perhatian pada masalah konsistensi, sedangkan yang kedua lebih memperhatikan masalah ketepatan (Kuncoro, 2013).

\section{Teknik Analisis Data}

\section{Uji Statistik Deskriptif}

Statistik deskriptif memberikan gambaran data dengan kriteria nilai rata-rata, standar deviasi, varian, maksimum, minimum, sum, range, kurtosis, dan skewness

\section{Uji Asumsi Klasik}

Sebelum data dianalisis lebih lanjut menggunakan analisis regresi berganda, terlebih dahulu dilakukan uji asumsi klasik yang terdiri dari: uji normalitas, uji multikolinieritas, dan uji heterokedastisitas.

\section{Uji Hipotesis}

Pengujian hipotesis dilakukan dengan menggunakan model analisis regresi berganda. Analisis linear berganda menurut Sugiyono dan Wibowo (2002:347) beberapa variable independen digunakan untuk memprediksi nilai dari variabel dependen. Sehingga analisis regresi linear berganda yang digunakan dapat dirumuskan sebagai berikut :

Fungsi Regresi Berganda :

$$
Y=\alpha+\beta_{1} X_{1}+\beta_{2} X_{2}+\beta_{3} X_{3}+\beta_{4} X_{4}+\beta_{5} X_{5}+\beta_{6} X_{6} \varepsilon
$$

Sementara itu, langkah-langkah untuk menguji pengaruh variabel independen, yaitu kompetensi, pengalaman, independensi, integritas, obyektifitas dan motivasi Auditor dilakukan dengan uji simultan dan uji parsial.

\section{ANALISIS HASIL PENELITIAN DAN PEMBAHASAN Hasil Penelitian Uji Validitas dan Realibilitas}

Pengujian validitas dilakukan untuk menguji apakah pertanyaan/pernyataan dalam kuesioner telah sesuai mengukur konsep yang dimaksud. Pengujian validitas dalam penelitian ini menggunakan Pearson Correlation yaitu dengan cara menghitung korelasi antara skor masing-masing butir pertanyaan dengan skor total. Jika korelasi antara skor masing-masing butir pertanyaan dengan skor total mempunyai tingkat signifikansi $<0,05$, maka butir pertanyaan tersebut dinyatakan valid dan sebaliknya (Ghozali, 2006). Hasil uji validitas atas Kompetensi, Pengalaman, Independensi, Obyektifitas, Integritas, Motivasi dan Kualitas Audit. Dimana jumlah Responden 60 orang artinya $n=60$. Dari nilai $r_{\text {tabel }} n=60$ yaitu 0,254 (5\%) dan 0,330 (1\%). Suatu kuesioner dikatakan reliabel atau handal jika jawaban seseorang terhadap pertanyaan adalah konsisten atau stabil dari waktu ke waktu. Pengujian ini dilakukan menggunakan teknik Cronbach Alpha. Suatu instrumen dapat dikatakan reliabel bila memiliki koefisien keandalan atau Cronbach Alpha $\geq 0,60$ (Ghozali, 2006).

\section{Uji Asumsi Klasik}

\section{Uji Normalitas}

Dasar pengambilan keputusan dalam uji normalitas yakni : jika nilai signifikansi lebih besar dari 0,05 maka data tersebut berdistribusi normal. Berdasarkan hasil pengujian pada tabel 5.13 dengan menggunakan Uji Kolmogorov Smirnov diatas, maka tingkat signifikansi residual error data sebesar 0.726 atau berada diatas 0.05 sehingga dapat disimpulkan bahwa residual error data terdistribusi dengan normal.

\section{Uji Multikolinearitas}

Dasar pengambilan keputusan pada uji multikolinearitas dapat dilakukan dengan dua cara yaitu melihat nilai Tolerance (1) Jika nilai tolerance lebih besar dari 0,10 maka artinya tidak terdapat multikolinearitas terhadap data yang diuji. (2) Jika nilai tolerance lebih kecil dari 0,10 maka artinya terdapat multikolinearitas terhadap data yang diuji. Melihat nilai VIF (Variance Inflation Factor) (1) Jika nilai VIF lebih kecil dari 10,00 maka artinya tidak terjadi multikolinearitas terhadap data yang diuji. (2) Jika nilai VIF lebih besar dari 10,00 maka 
artinya terjadi multikolinearitas terhadap data yang diuji. Pada tabel 5.14, Dengan melihat nilai tolerance lebih besar dari 0,10 pada setiap variabel independen yaitu Kompetensi 0,960, pengalaman 0,704 ,independensi 0,780 , obyektifitas 0.423 , integritas 0,475 dan motivasi 0,876 serta juga dengan melihat nilai VIF setiap variabel independen lebih kecil dari 10,00, yaitu Kompetensi 1,042, pengalaman 1,420, independensi 1,282, obyektifitas 2,366, integritas 2,106 dan motivasi 1,142, maka dapat disimpulkan bahwa antar variabel penelitian bebas efek multikolinearitas.

\section{Uji Heteroskedastisitas}

Dasar pengambilan keputusan pada uji heteroskedastisitas yakni :

1. Jika nilai signifikansi lebih besar dari 0,05, kesimpulannya adalah tidak terjadi heteroskedastisitas

2. Jika nilai signifikansi lebih kecil dari 0,05 , kesimpulannya adalah terjadi heteroskedastisitas.

Variabel independen yaitu Kompetensi 0,521, pengalaman 0,902, independensi 0,224, obyektifitas 0,190 , integritas 0,946 dan motivasi 0,182 , tingkat signifikansi variabel independen terhadap residual error data berada diatas 0.05 , sehingga dapat disimpulkan bahwa varians data penelitian bebas efek heteroskedastisitas.

\section{Analisis Regresi Linear Berganda}

Hasil analisis data menggunakan analisis regresi Linear berganda dapat dilihat pada table 5.16 berikut ini :

Tabel 5.16 Hasil Analisis Regresi Linear Berganda

\begin{tabular}{|c|c|c|c|c|c|c|}
\hline & & \multicolumn{2}{|c|}{$\begin{array}{l}\text { Unstandardized } \\
\text { Coefficients }\end{array}$} & \multirow{2}{*}{$\begin{array}{c}\text { Standardized } \\
\text { Coefficients }\end{array}$} & \multirow[b]{2}{*}{$t$} & \multirow[b]{2}{*}{ Sig. } \\
\hline \multicolumn{2}{|c|}{ Model } & $B$ & Std. Error & & & \\
\hline & (Constant) & 3.588 & 11.348 & & .316 & .753 \\
\hline & (X1) Kompetensi & .005 & .074 & .006 & .066 & .948 \\
\hline & (X2) Pengalaman & .105 & .122 & .084 & .856 & .396 \\
\hline & (X3) Independensi & .116 & .106 & .102 & 1.096 & .278 \\
\hline & (X4) Obyektifitas & .589 & .277 & .268 & 2.127 & .038 \\
\hline & (X5) Integritas & .451 & .149 & .359 & 3.019 & .004 \\
\hline & (X6) Motivasi & .310 & .098 & .276 & 3.158 & .003 \\
\hline
\end{tabular}

Sumber: Data hasil pengolahan SPSS

Berdasarkan hasil perhitungan dengan menggunakan bantuan software SPSS version 22.00 seperti pada tabel 5.16 maka persamaan regresi berganda yang diperoleh adalah sebagai berikut :

$$
\begin{gathered}
Y=\alpha+\beta_{1} X_{1}+\beta_{2} X_{2}+\beta_{4} X_{4}+\beta_{5} X_{5}+\beta_{6} X_{6}+e \\
Y=3,588+0,005 X_{1}+0,105 X_{2}+0,116 X_{3}+0,589 X_{4}+0,451 X_{5}+0,310 X_{6}+e
\end{gathered}
$$

Persamaan regresi berganda di atas dapat dijelaskan sebagai berikut.

a. Dengan Interpretasi Konstanta $\alpha$ sebesar 3,588 menunjukkan bahwa apabila kompetensi $\left(\mathrm{X}_{1}\right)$, pengalaman $\left(\mathrm{X}_{2}\right)$, independensi $\left(\mathrm{X}_{3}\right)$, obyektifitas $\left(\mathrm{X}_{4}\right)$, integritas $\left(\mathrm{X}_{5}\right)$ dan motivasi $\left(\mathrm{X}_{6}\right)$ audit dianggap konstan atau sama dengan nol (0), maka besarnya kualitas audit aparat Inspektorat Provinsi Sulawesi Utara 3,588 satuan skor.

b. Nilai $\beta_{1}$ yang merupakan koefisien regresi dari variabel $\mathrm{X}_{1}$ (kompetensi) sebesar 0,005 ini berarti bahwa jika kompetensi meningkat sebesar 1 satuan skor, maka akan mengalami peningkatan nilai kualitas audit sebesar 0,005 satuan skor dari kondisi sebelumnya, dengan asumsi variabel lainnya tetap. Hal ini berarti pula bahwa terdapat hubungan yang positif dan searah antara kompetensi dengan kualitas audit. Dengan kata lain adanya peningkatan pada variabel kompetensi $\left(\mathrm{X}_{1}\right)$, akan meningkatkan kualitas audit (Y) Inspektorat Provinsi Sulawesi Utara. 
c. Nilai $\beta_{2}$ yang merupakan koefisien regresi dari variabel $\mathrm{X}_{2}$ (pengalaman) sebesar 0,105 ini berarti bahwa jika pengalaman meningkat sebesar 1 satuan skor, maka akan mengalami peningkatan nilai kualitas audit sebesar 0,105 satuan skor dari kondisi sebelumnya, dengan asumsi variabel lainnya tetap. Hal ini berarti pula bahwa terdapat hubungan yang positif dan searah antara pengalaman dengan kualitas audit. sehingga adanya peningkatan pada variabel pengalaman $\left(\mathrm{X}_{2}\right)$, akan meningkatkan kualitas audit (Y) Inspektorat Provinsi Sulawesi Utara.

d. Nilai $\beta_{3}$ yang merupakan koefisien regresi dari variabel $\mathrm{X}_{3}$ (independensi) sebesar 0,116 ini berarti bahwa jika independensi meningkat sebesar 1 satuan skor, maka akan mengalami peningkatan nilai kualitas audit sebesar 0,116 satuan skor dari kondisi sebelumnya, dengan asumsi variabel lainnya tetap. Hal ini berarti pula bahwa terdapat hubungan yang positif dan searah antara independensi dengan kualitas audit. sehingga adanya peningkatan pada variabel independensi $\left(\mathrm{X}_{3}\right)$, akan meningkatkan kualitas audit (Y) Inspektorat Provinsi Sulawesi Utara.

e. Nilai $\beta_{4}$ yang merupakan koefisien regresi dari variabel $\mathrm{X}_{4}$ (obyektifitas) sebesar 0,589 ini berarti bahwa jika obyektifitas meningkat sebesar 1 satuan skor, maka akan mengalami peningkatan nilai kualitas audit sebesar 0,589 satuan skor dari kondisi sebelumnya, dengan asumsi variabel lainnya tetap. Hal ini berarti pula bahwa terdapat hubungan yang positif dan searah antara obyektifitas dengan kualitas audit. sehingga adanya peningkatan pada variabel obyektifitas $\left(\mathrm{X}_{4}\right)$, akan meningkatkan kualitas audit (Y) Inspektorat Provinsi Sulawesi Utara.

f. Nilai $\beta_{4}$ yang merupakan koefisien regresi dari variabel $\mathrm{X}_{5}$ (integritas) sebesar 0,451 ini berarti bahwa jika integritas meningkat sebesar 1 satuan skor, maka akan mengalami peningkatan nilai kualitas audit sebesar 0,451 satuan skor dari kondisi sebelumnya, dengan asumsi variabel lainnya tetap. Hal ini berarti pula bahwa terdapat hubungan yang positif dan searah antara integritas dengan kualitas audit. Dengan kata lain adanya peningkatan pada variabel integritas $\left(\mathrm{X}_{5}\right)$, akan meningkatkan kualitas audit $(\mathrm{Y})$ Inspektorat Provinsi Sulawesi Utara.

g. Nilai $\beta_{6}$ yang merupakan koefisien regresi dari variabel $\mathrm{X}_{6}$ (motivasi) sebesar 0,005 ini berarti bahwa jika motivasi meningkat sebesar 1 satuan skor, maka akan mengalami peningkatan nilai kualitas audit sebesar 0,005 satuan skor dari kondisi sebelumnya, dengan asumsi variabel lainnya tetap. Hal ini berarti pula bahwa terdapat hubungan yang positif dan searah antara motivasi dengan kualitas audit. Dengan kata lain adanya peningkatan pada variabel motivasi $\left(\mathrm{X}_{6}\right)$, akan meningkatkan kualitas audit (Y) Inspektorat Provinsi Sulawesi Utara.

\section{Pengujian Hipotesis Secara Simultan (Uji F)}

Dari hasil output uji koefisien regresi secara simultan/bersama-sama (Uji F) dapat diketahui nilai F pada Tabel 5.17 berikut :

Tabel 5.17 Hasil Pengujian Simultan (Uji F)

\begin{tabular}{|ll|r|r|r|r|r|}
\hline Model & & Sum of Squares & df & Mean Square & F & Sig. \\
\hline 1 & Regression & 2144.664 & 6 & 357.444 & 16.034 & $.000^{\mathrm{b}}$ \\
& Residual & 1181.519 & 53 & 22.293 & & \\
& Total & 3326.183 & 59 & & & \\
\end{tabular}

a. Dependent Variable: Kualitas Audit

b. Predictors: (Constant), komptensi, pengalaman, independensi, obyektifitas, integritas, motivasi

Sumber: Hasil Olah data dengan SPSS

Berdasarkan hasil pengolahan data pada tabel 5.17, menunjukkan bahwa hasil uji $\mathrm{F}$ diperoleh $F_{\text {hitung }}=16,034$, sehingga $F_{\text {hitung }}=16,034>F_{\text {tabel }}=2,39$ dengan menggunakan tingkat nilai signifikansi $\mathrm{P}=0,000<\alpha=0,005$ sehingga Ha diterima dan Ho ditolak maka dapat disimpulkan bahwa variabel Kompetensi $\left(\mathrm{X}_{1}\right)$, pengalaman $\left(\mathrm{X}_{2}\right)$, independensi $\left(\mathrm{X}_{3}\right)$, 
obyektifitas $\left(\mathrm{X}_{4}\right)$, integritas $\left(\mathrm{X}_{5}\right)$ dan motivasi $\left(\mathrm{X}_{6}\right)$ secara bersama-sama menunjukan hasil signifikan yang berarti bahwa model penelitian adalah fit dan seluruh variabel independen secara simultan adalah signifikan terhadap variabel dependen yaitu kualitas audit

\section{Pengujian Hipotesis Secara Parsial (Uji t)}

Pengujian hipotesis secara parsial (uji t) dilakukan untuk mengetahui besarnya pengaruh masing-masing variabel independen (X) secara individual terhadap variabel dependen (Y) secara parsial. Hasil uji t ini pada output SPSS dapat dilihat pada tabel 5.18 berikut :

Tabel 5.18

Hasil Pengujian Parsial (Uji t)

Coefficients

\begin{tabular}{|c|c|c|c|c|c|c|}
\hline \multirow{2}{*}{\multicolumn{2}{|c|}{ Model }} & \multicolumn{2}{|c|}{$\begin{array}{l}\text { Unstandardized } \\
\text { Coefficients }\end{array}$} & \multirow{2}{*}{$\begin{array}{c}\begin{array}{c}\text { Standardized } \\
\text { Coefficients }\end{array} \\
\text { Beta } \\
\end{array}$} & \multirow[b]{2}{*}{$\mathrm{t}$} & \multirow[b]{2}{*}{ Sig. } \\
\hline & & $B$ & Std. Error & & & \\
\hline & (Constant) & 3.588 & 11.348 & & .316 & .753 \\
\hline & $\mathrm{X} 1$ & .005 & .074 & .006 & .066 & .948 \\
\hline & $\mathrm{X} 2$ & .105 & .122 & .084 & .856 & .396 \\
\hline & X3 & .116 & .106 & .102 & 1.096 & .278 \\
\hline & $X 4$ & .589 & .277 & .268 & 2.127 & .038 \\
\hline & $\mathrm{X} 5$ & .451 & .149 & .359 & 3.019 & .004 \\
\hline & $\mathrm{X} 6$ & .310 & .098 & .276 & 3.158 & .003 \\
\hline
\end{tabular}

a. Dependent Variable: $Y$

Sumber: Hasil Olah data dengan SPSS

Uji Koefisien Korelasi (R) dan Koefisien Determinasi (adjusted R2)

Tabel berikut ini merupakan hasil uji koefisien korelasi dan determinasi atas penelitian yang dilakukan.

Tabel 5.19 Hasil Uji Koefisien Korelasi dan Koefisien Determinasi

Model Summary

\begin{tabular}{|c|c|c|c|c|}
\hline Model & $\mathrm{R}$ & R Square & Adjusted R Square & Std. Error of the Estimate \\
\hline 1 & $.803^{\mathrm{a}}$ & .645 & . 605 & 4.72153 \\
\hline
\end{tabular}

\footnotetext{
a. Predictors: (Constant), X6, X1, X5, X3, X2, X4

b. Dependent Variable: $Y$

Sumber: Hasil Olah data dengan SPSS
}

Berdasarkan tabel 5.19, koefisien korelasi (R) sebesar 0,803 menunjukkan bahwa hubungan (korelasi) antara variabel independen dengan variabel dependen merupakan hubungan yang sangat kuat. Artinya kompetensi, pengalaman, independensi, obyektifitas, integritas dan motivasi mempunyai hubungan yang sangat kuat terhadap kualitas audit, karena mendekati nilai 1. Santoso (2001) menyatakan bahwa untuk regresi dengan lebih dari dua variabel bebas digunakan adjusted $R^{2}$ sebagai koefisien determinasi. Jika nilai adjusted $R^{2}$ sama dengan 0, maka variasi variabel independen yang digunakan dalam model tidak menjelaskan sedikitpun variasi variabel dependen. Sebaliknya adjusted $R^{2}$ sama dengan 1 , maka variasi variabel independen yang digunakan dalam model menjelaskan $100 \%$ variasi variabel dependen. Berdasarkan tabel 5.19, nilai adjusted $\mathrm{R}^{2}$ adalah 0,605 yang artinya peningkatan kualitas audit sebesar $60,5 \%$ dipengaruhi oleh kompetensi, pengalaman, independensi, obyektifitas, integritas dan motivasi, sedangkan sisanya 39,5\% dipengaruhi oleh faktor lain di luar penelitian ini atau dijelaskan oleh variabel lain yang tidak dimasukkan dalam penelitian ini. 


\section{Pembahasan}

\section{Pengaruh Kompetensi terhadap Kualitas Audit}

Tidak adanya pengaruh signifikan antara kompetensi terhadap kualitas audit karena auditor/aparat yang ada di inspektorat memiliki berbagai latar belakang pendidikan yang berbeda - beda dimana tidak semuanya memiliki latar belakang pendidikan akuntansi dan belum meratanya keikutsertaan dalam mengikuti pendidikan dan pelatihan teknis dan fungsional dalam rangka meningkatkan pengetahuan dan keahlian tentang audit.

Simpulan dari penelitian ini bahwa kompetensi tidak berpengaruh sinifikan terhadap kualitas audit Auditor Inspektorat Provinsi Sulawesi Utara. Artinya kompetensi auditor yang rendah akan berdampak pada rendahnya kualitas audit yang dihasilkan. Sehingga diharapkan auditor inspektorat mampu mengembangkan potensi diri dalam aspek pengetahuan, keahlian, dan sikap perilaku melalui pendidikan dan pelatihan tentang audit agar bisa meningkatkan kualitas audit.

\section{Pengaruh pengalaman terhadap Kualitas Audit}

Ternyata banyaknya penugasan audit dan lamanya pengalaman kerja yang dimiliki auditor bukan jaminan bahwa auditor dapat meningkatkan kualitas hasil pemeriksaannya sehingga pengalaman tidak berpengaruh terhadap kualitas audit Auditor Inspektorat Provinsi Sulawesi Utara, karena faktor internal dalam diri auditor juga turut mempengaruhi kualitas audit. Oleh karena itu diharapkan auditor tidak berpuas diri dengan lamanya pengalaman audit yang dimiliki dengan tetap mengikuti perkembangan peraturan perundang - undangan yang ada serta tetap mengikuti kode etik dan standar audit yang telah ditetapkan untuk terus mempertahankan kualitas audit.

\section{Pengaruh Independensi terhadap Kualitas Audit}

Independensi merupakan salah satu karakteristik terpenting bagi auditor dan merupakan dasar dari prinsip integritas dan objektivitas. Independensi itu sendiri bukan saja saat pelaksanaan audit namun dimulai dari perencanaan program audit yang harus bebas dari intervensi pihak manapun. Bagi auditor/aparat inspektorat sebagai bagian dari aparat pengawasan internal pemerintah, yang pada dasarnya melakukan audit terhadap Pemerintah Daerah dan auditeenya adalah sesama PNS yang tidak menutup kemungkinan adalah teman ataupun saudara serta juga adanya intervensi dari pihak lain yang bisa memungkinkan adanya pembatasan ruang lingkup pelaksanaan audit itu sendiri. Sehingga mutlak bagi aparat inspektorat memiliki independensi pada saat melakukan penugasan profesionalnya.

Dengan demikian dapatlah disimpulkan bahwa dari penelitian ini independensi tidak berpengaruh signifikan terhadap kualitas audit Auditor Inspektorat Provinsi Sulawesi Utara. Artinya rendahnya independensi auditor akan berdampak pada rendahnya kualitas audit yang dihasilkan.

\section{Pengaruh obyektifitas terhadap kualitas audit}

Sebagaimana yang diatur dalam Permenpan No. PER/05/M.PAN/03/2008 tentang kode etik APIP menyebutkan bahwa "Obyektifitas diperlukan agar Auditor APIP menjunjung tinggi ketidakberpihakan professional dalam mengumpulkan, mengevaluasi, dan memproses data/informasi auditi. Auditor APIP membuat penilaian seimbang atas semua situasi yang relevan dan tidak dipengaruhi oleh kepentingan sendiri atau orang lain dalam mengambil keputusan."

Adanya pengaruh positif dan signifikan variabel obyektifitas terhadap kualitas audit dalam penelitian ini menunjukkan, bahwa semakin tinggi obyektifitas yang dimiliki oleh auditor pada Inspektorat Provinsi Sulawesi Utara, maka kualitas audit yang dihasilkan akan semakin baik pula

\section{Pengaruh Integritas terhadap Kualitas Audit}

Adanya pengaruh positif dan signifikan variabel integritas terhadap kualitas audit dalam penelitian ini menunjukkan, bahwa semakin tinggi integritas yang dimiliki oleh auditor 
Inspektorat Provinsi Sulawesi Utara, maka kualitas audit yang dihasilkan akan semakin baik pula. Dimana integritas tersebut harus didukung oleh kepribadian auditor yang dilandasi oleh unsur jujur, berani, bijaksana, dan bertanggung jawab.

\section{Pengaruh Motivasi terhadap Kualitas Audit}

Dalam modul Pusdiklatwas BPKP (2007) tentang kepemimpinan seorang ketua tim harus mampu memotivasi anggotanya, sehingga Tim dapat dikembangkan jika para anggota di dalam tim (termasuk ketuanya) merasa puas bekerja dan ada motivasi untuk melaksanakan tugas-tugasnya. Selanjutnya dalam modul Pusdiklatwas BPKP (2008) tentang Supervisi audit, menyatakan bahwa dalam suatu tim yang melaksanakan audit perlu tercipta suasana yang memberikan motivasi kerja, hal ini merupakan salah satu tugas pokok dari supervisor atau pengendali teknis. Sehingga adanya supervisi yang baik dari ketua tim terhadap anggota tim serta supervisi dari pengendali teknis kepada tim audit maka akan menambah semangat dari auditor/aparat untuk meningkatkan kualitas auditnya. Adanya pengaruh positif dan signifikan variabel motivasi terhadap kualitas audit dalam penelitian ini menunjukkan, bahwa semakin baik motivasi yang dimiliki oleh Auditor Inspektorat Provinsi Sulawesi Utara, maka kualitas audit yang dihasilkan akan semakin baik pula.

\section{KESIMPULAN DAN SARAN \\ Kesimpulan}

Penelitian ini bertujuan untuk mengetahui pengaruh kompetensi, pengalaman, independensi, obyektifitas, integritas dan motivasi terhadap kualitas audit Auditor Inspektorat Provinsi Sulawesi Utara. Berdasarkan hasil penelitian dapat diambil kesimpulan sebagai berikut :

1. kompetensi berpengaruh positif namun tidak berpengaruh signifikan terhadap kualitas audit artinya kompetensi auditor yang rendah akan berdampak pada rendahnya kualitas audit.

2. Pengalaman berpengaruh positif namun tidak berpengaruh signifikan terhadap kualitas audit sehingga dapat diartikan bahwa lamanya pengalaman kerja yang dimiliki bukan jaminan dapat meningkatkan kualitas audit.

3. Independensi berpengaruh positif namun tidak berpengaruh signifikan terhadap kualitas audit. Artinya rendahnya independensi akan berdampak pada rendahnya kualitas audit.

4. Obyektifitas berpengaruh positif dan signifikan terhadap kualitas audit sehingga semakin tinggi obyektifitas maka kualitas audit yang dihasilkan akan semakin baik.

5. Integritas berpengaruh positif dan signifikan terhadap kualitas audit artinya semakin baik integritas maka semakin baik kualitas audit yang dihasilkan.

6. Motivasi berpengaruh positif dan signifikan terhadap kualitas audit sehingga semakin tinggi motivasi maka kualitas audit yang dihasilkan akan semakin baik.

\section{Saran}

Saran untuk penelitian berikutnya:

1. Bagi peneliti selanjutnya diharapkan dapat memperluas sampel penelitian, dengan mengambil sampel pada Inspektorat kabupaten dan kota yang ada di provinsi Sulawesi Utara.

2. Peneliti selanjutnya dapat mempertimbangkan menggunakan metode - metode campuran kuantitatif dan kualitatif dalam penelitian, dimana metode kualitatif digunakan untuk menjelaskan hasil yang diperoleh dari metode kuantitatif sehingga dapat memperoleh kesimpulan yang sesuai dengan kondisi sebenarnya.

3. Peneliti selanjutnya diharapkan dapat mengembangkan kuesioner lebih lanjut mengenai supervisi audit, kemampuan auditor dalam mendeteksi kecurangan, audit investigative, dan probity audit. 


\section{DAFTAR PUSTAKA}

Ardana.I.K., N.W. Mujiati, dan I.W.M, Utama, 2012. Manajemen Sumber Daya Manuasia. Yogyakarta : Penerbit Graha Ilmu

Arens. A. A., R.J. Elder., dan M.S, Beasley. 2015. Auditing dan Jasa Assurance. Jilid1. Terjemahan. Edisi kelimabelas. Jakarta : Penerbit Erlangga

Asosiasi Auditor Intern Pemerintah Indonesia (AAIPI) No. S-879/D2/JF/2013 tentang Standar Audit Intern Pemerintah Indonesia.

Asih, Dwi Ananing Tyas. 2006. Pengaruh Pengalaman Terhadap Peningkatan Keahlian Auditor Dalam Bidang Auditing. Skripsi. Fakultas Ekonomi Universitas Islam Indonesia. Yogyakarta.

Ayuningtyas H. Y. 2012. Pengaruh Pengalaman Kerja, Independensi, Obyektifitas, Integritas dan Kompetensi Terhadap Kualitas Audit (Studi Kasus Pada Auditor Inspektorat Kota/Kabupaten di Jawa Tengah). Skripsi. Fakultas Ekonomika dan Bisnis Universitas Diponegoro. Semarang

BPKP, 2007. Kepemimpinan. Edisi Keempat. Diklat Penjenjangan Auditor Tingkat Ketua Tim.

, 2008. Supervisi Audit. Edisi Keempat. Diklat Pembentukan Auditor Pengendali Teknis.

-, 2008. Kode Etik dan Standar Audit. Edisi Kelima. Diklat Pembentukan Auditor Ahli.

, 2009. Auditing. Edisi Kelima. Diklat Pembentukan Auditor Ahli.

2013. Pimpinan APIP Se-Sulawesi Sepakat Tingkatkan Kapabilitas Auditor. http://www.bpkp.go.id/berita/read/11063/25/ diakses tanggal 10 Maret tahun 2016

Badjuri. A, 2012. "Analysis Faktor-Faktor Yang Mempengaruhi Kualitas Hasil Pemeriksaan Audit Sektor Publik (Studi Empiris Pada BPKP Perwakilan Jawa Tengah)". Dinamika Akuntansi, Keuangan dan Perbankan, Nopember 2012, Hal: 120 - 135 Vol. 1, No. 2

Cahyat, A. 2004. Sistem Pengawasan terhadap Penyelenggaraan Pemerintah Daerah Kabupaten. Pembahasan Peraturan Perundangan di Bidang Pengawasan. Governance Brief Number 3

DeAngelo. L.E. 1981a. Auditor independence, "low balling" and disclosure regulation. Journal of Accounting and Economics 3, 113-127

DeAngelo, L.E. 1981b. "Auditor Size and Audit Quality". Journal of Accounting and Economics. July. pp. 183-199. University of Pennsylvania, Philadelphia, PA 19104, USA

Efendy, Muh. Taufiq. 2010. Pengaruh Kompetensi, Independensi, Dan Motivasi Terhadap Kualitas Audit Aparat Inspektorat Dalam Pengawasan Keuangan Daerah (Studi Empiris Pada Pemerintah Kota Gorontalo).Tesis. Program Studi Magister Sains Akuntansi Program Pascasarjana. Universitas Diponegoro : Jawa Tengah.

Estikawati F. 2016. Pengaruh Keahlian, Independensi, Etika Terhadap Kualitas Audit Pada Badan Pemeriksa Keuangan Republik Indonesia Perwakilan Provinsi Lampung. Tesis. Program Pasca Sarjana Ilmu Akuntansi Universitas Lampung. Bandar Lampung

Ghozali, I. 2006. Aplikasi Analisis Multivariat dengan Program SPSS. Edisi 3. BP Undip. Semarang.

Government Internal Audit Profession. 2007. Government Internal Audit Competency Framework

Government Accountability Office. (2011). Government auditing Standard. Revision

Hanjani, A., 2014. Pengaruh Etika Auditor, Pengalaman Auditor, Fee Audit, Dan Motivasi Auditor Terhadap Kualitas Audit (Studi pada Auditor KAP Di Semarang). Skripsi 
tidak dipublikasikan. Fakultas Ekonomika dan Bisnis Universitas Diponegoro Semarang.

Herliansyah, Yudhi. Meifida Ilyas. 2006. Jurnal. Pengaruh Pengalaman Auditor Terhadap Penggunaan Bukti Tidak Relevan Dalam Auditor Judgment. SNA IX. Padang.

Harhinto, T. 2004. Pengaruh Keahlian dan Independensi terhadap Kualitas Audit, Studi Empiris pada KAP di Jawa Timur. Tesis tidak dipublikasikan. Universitas Diponegoro Semarang.

The Institute of Internal Auditors. (2012). International standards for the professional practice of internal auditing (standards)

IAASB (International Auditing and Assurance Standards Board). 2013. A Framework of Audit Quality.

Kuncoro, M. 2014. Otonomi Daerah Menuju Era Baru Pembangunan Daerah. Jakarta : Penerbit Erlangga

\section{Penerbit Erlangga}

Lamuda. 2013. Pengaruh Pengalaman Kerja, Independensi, Objektivitas, Integritas, Kompetensi dan Komitmen Organisasi Terhadap Kualitas Audit. Skripsi. Fakultas Ekonomi dan Bisnis Universitas Muhammadiyah Surakarta. Surakarta.

Lowensohn dan Collins. 2001. The Role and Perceptions of Independent Audit Partners in the Governmental Audit Market. Journal of Accounting and the Public Interest. Volume 1

Lubis. 2009. Pengaruh Keahlian, Independensi, Kecermatan Professional dan Kepatuhan Pada Kode Etik Terhadap Terhadap Kualitas Auditor Pada Inspektorat Sumatera Utara. Tesis. Magister Sains Ilmu Akuntansi Universitas Sumatera Utara.

Luthans F. 2011. Organizational Behavior : An Evidence-Based Approach. Twelfth Edition. New York : McGraw-Hill/Irwin

Mabruri dan Winarna, 2010. Analisis Faktor-Faktor Yang Mempengaruhi Kualitas Hasil Audit di Lingkungan Pemerintah Daerah. Symposium nasional akuntansi XIII

Mardiasmo. 2009. Akuntansi Sektor Publik. Yogyakarta: Andi Yogyakarta

Martini. 2011. Analisis Faktor-Faktor Yang Mempengaruhi Kualitas Audit. Analisis FaktorFaktor Yang Mempengaruhi Kualitas Hasil Audit. Universitas Budi Luhur. Jakarta

Masrizal. 2010. Pengaruh Pengalaman Dan Pengetahuan Audit Terhadap Pendeteksian Temuan Kerugian Daerah (Studi Pada Auditor Inspektorat Aceh). Jurnal Telaah dan Riset Akuntansi. Volume 3 nomor 2 juli 2010 hal. 173 - 194

McClave,J.T., P.J, Benson, dan T. Sincich. 2011. Statistik Untuk Bisnis dan Ekonomi. Jilid 1. Terjemahan. Edisi kesebelas. Jakarta : Penerbit Erlangga

Mulyadi . 2002. Auditing. Jakarta : Penerbit Salemba Barat

Musdar, Muh., Syarifuddin, Arifuddin, (2014). Analisis faktor yang mempengaruhi kualitas audit Aparat Pengawas Intern Pemerintah (APIP) : Studi Empiris pada Inspektorat kabupaten Wakatobi. Tesis. Program Magister Akuntansi Fakultas Ekonomi dan Bisnis Universitas Hasanuddin. Makasar

Mufidah. 2015. Analisis Pengaruh Independensi, Objektifitas, Integritas, kompeensi, Pengalaman Kerja dan Skeptisme Profesional terhadap Kualitas Hasil Pemeriksaan di Lingkungan Inspektorat Provinsi Jambi. Jurnal Akuntasi dan Keuangan Unja Volume 2 tahun 2015.

Muflihin, M. Hizbul. 2009. Aplikasi dan Implikasi Teori Behaviorisme dalam Pembelajaran (Analisis Strategis Inovasi Pembelajaran). Jurnal Ilmiah Kependidikan Vol. I No.1 hal : 123 . 
Nataline. 2007. Pengaruh Batasan Waktu Audit, Pengetahuan Akuntansi dan Auditing, Bonus dan Pengalaman terhadap Kualitas Audit pada Kantor Akuntan Publik di Semarang. Skripsi. Jurusan Akuntansi. Fakultas Ekonomi. UNNES.

Nirwana. 2014. Pengaruh Kompetensi, Independensi, Akuntabilitas dan Motivasi Terhadap Kualitas Audit Aparat Inspektorat Dalam Pengawasan Keuangan Daerah (Studi Empiris pada Pemerintah Kota Salatiga). Skripsi. Fakultas Ekonomika dan Bisnis Universitas Kristen Satya Wacana.

Oklivia dan Marlinah. 2014. Pengaruh Kompetensi, Independensi dan Faktor - Faktor Dalam Diri Auditor lainnya Terhadap Kualitas Audit. Jurnal Bisnis dan Akuntansi. Vol. 16, No. 2, Desember 2016 : 143 - 157

Pasaribu Sandi H. 2015. Pengaruh kecakapan professional, Independensi dan lama bekerja terhadap hasil pemeriksaan auditor internal pada Inspektorat kabupaten/kota di Provinsi Sulawesi Utara. Tesis. Program Magister Akuntansi Fakultas Ekonomi dan Bisnis Universitas Sam Ratulangi

PCAOB (Public Company Accounting Oversight Board). 2013. Standing Advisory Group Meeting Discussion - Audit Quality Indicators.

Peraturan Daerah Nomor 6 Tahun 2011 tentang Perubahan atas Peraturan Daerah Nomor 4 Tahun 2008 tentang Organisasi dan Tata Kerja Inspektorat, Badan Perencanaan Pembagunan Daerah, Lembaga Teknis Daerah dan Lembaga Lain Provinsi Sulawesi Utara

Peraturan Gubernur Sulawesi Utara Nomor 6 Tahun 2011 tentang Perubahan Peraturan Gubernur Sulawesi Utara Nomor 63 Tahun 2008 tentang Uraian Tugas Inspektorat Provinsi Sulawesi Utara.

Peraturan Meteri Negara Pendayagunaan Aparatur Negara Nomor : PER/04/M.PAN/03/2008 tentang Kode Etik Aparat Pengaweas Internal Pemerintah.

Peraturan Meteri Negara Pendayagunaan Aparatur Negara Nomor : PER/05/M.PAN/03/2008 tentang Standar Audit Aparat Pengawas Internal Pemerintah.

Peraturan Menteri Negara Pendayagunaan Aparatur Negara Nomor 19 tahun 2009 tentang Pedoman Kendali Mutu Audit

Peraturan Menteri Dalam Negeri Nomor 64 tahun 2007 tentang Pedoman Teknis Organisasi dan Tata Kerja Inspektorat Provinsi dan Kabupaten/Kota.

Peraturan Pemerintah Nomor 60 Tahun 2008 tentang Sistem Pengendalian Intern Pemerintah $(S P I P)$

Peraturan Kepala Badan Pengawas Keuangan dan Pembangunan Republik Indonesia nomor 16 tahun 2015 tentang Pedoman Teknis Peningkatan Kapabilitas Aparat Pengawasan Intern Pemerintah.

Perdani dan Suranta. 2013. Pengaruh kompetensi dan Independensi Auditor Terhadap Kualitas Audit Investeigatif pada Kantor Perwakilan BPK-RI Yogyakarta. Fakultas Ekonomi Universitas sebelas maret. Jurnal Akuntansi dan Bisnis Vol 14 no. 1 Februari 2013.

Prasetyo, D. F. 2016. Pengaruh Independensi, Kompetensi, Integritas, Objektifitas dan Pengalaman Kerja Terhadap Kualitas Audit. Skripsi. Fakultas Ekonomi dan Bisnis Universitas Muhamadiyah Surakarta. Surakarta

Robbins, S. P., 1996. Organizational Behavior Concept Controversies applications. Seventh edition. England : Pearson Education Limited

Santoso, Singgih. 2001. SPSS Versi Mengolah Data Statistik Secara Profesional. Jakarta: PT. Elex Media Komputindo

Samelson, D., et al. 2006. The Determinants Of Perceived Audit Quality And Auditee Satisfaction In Local Government. Journal of Public Budgeting, Accounting and Financial Management, 18 (2), 139 - 166 
Sumiok C. 2012. Pengaruh Kompetensi, Independensi, dan Motivasi Terhadap Kualitas Audit Aparat Inspektorat Dalam Pengawasan Keuangan Daerah di Provinsi Sulawesi Utara. Tesis. Program Magister Akuntansi Fakultas Ekonomi dan Bisnis Universitas Sam Ratulangi. Manado

Susmanto, B. 2008. Pengawasan Intern pada Kementerian Koordinator Bidang Kesejahteraan Rakyat. Kementerian Koordinator Bidang Kesejahteraan Rakyat. http://www.menkokesra.go.id/content/view/117/323/ diakses tanggal 10 Maret tahun 2016

Sukriah. I, B. Akram, dan A. Inapty. 2009. "Pengaruh Pengalaman Kerja, Independensi, Obyektifitas, Integritas dan Kompetensi Terhadap Kualitas Hasil Pemeriksaan". Simposium Nasional Akuntansi XII. Palembang.

Sugiyono. 2014. Metode Penelitian Kuantitatif, Kualitatif Dan $R \& D$. Bandung: Penerbit Alfabeta

Sekolah Tinggi Akuntansi Negara. 2007. Modul Manajemen Fungsi Audit Internal Sektor Publik

Tinangon, J. J. 2012. "Pengaruh Motivasi, Independensi dan Kompetensi Auditor Terhadap Komitmen Organisasi, Kepuasan Kerja Dan Kinerja Auditor Inspektorat Kabupaten/Kota di Sulawesi Utara". Disertasi. Program Pasca Sarjana Universitas Hasanudin. Makasar

Tubb, Richard, M. 1992. "The Effect of Experience on the Auditors Organization and Amount of Knowledge." The Accounting Review, (October): vol. 67. No. 4: 783-801.

Wirasuasti, N. W., 2014. "Pengaruh Kompetensi, Independensi, dan Motivasi Terhadap Kualitas Audit Aparat Inspektorat Dalam Pengawasan Keuangan Daerah (Studi Empiris pada Inspektorat Pemerintah Kabupaten Bangli dan Inspektorat Pemerintah Kabupaten Buleleng)". e-Journal S1 Ak Universitas Pendidikan Ganesha Jurusan Akuntansi Program S1 (Volume 2 No: 1 Tahun 2014)

Yuniarsih, T., dan Suwatno. 2013. Manajemen Sumber Daya Manusia. Bandung : Penerbit Alfabeta

Zawitri, S. 2009. "Analisis Faktor-Faktor Penentu Kualitas Audit yang dirasakan dan Kepuasan Auditee di Pemerintahan Daerah (Studi Lapangan pada Pemerintah Daerah KalBar tahun 2009)". Tesis. Program Studi Magister Sains Akuntansi Program Pascasarjana.Universitas Diponegoro : Jawa Tengah. 